\title{
Ethibond Suture Granuloma following Tibialis Anterior Tendon Transfer Mimicking Osteomyelitis of Foot
}

\author{
${ }^{1}$ Nirmal Raj Gopinathan, ${ }^{2}$ Mandeep S Dhillon, ${ }^{3}$ Balaji Saibaba, ${ }^{4}$ Siva Swaminathan Santhanam \\ ${ }^{5}$ Rajendra Kumar Kanojia
}

\begin{abstract}
Tibialis anterior tendon transfer is routinely done for the correction of dynamic supination deformity of foot in children with congenital talipes equinovarus (CTEV). Surgeons commonly make use of a nonabsorbable suture-'ethibond number 2 ' for anchoring the transferred tendon to the new recipient site. We would like to report a case of suture granuloma following tibialis anterior tendon transfer in a 4 years old child, presenting with a swelling and discharging sinus clinically mimicking osteomyelitis. Unlike osteomyelitis, the patient did not have fever or pain clinically, nor was any organism detected microbiologically. The clinical presentation and the successful management of the case have been described in detail along with relevant review of literature.
\end{abstract}

Keywords: Club foot, Ethibond, Suture granuloma, Tendon transfer.

How to cite this article: Gopinathan NR, Dhillon MS, Saibaba B, Santhanam SS, Kanojia RK. Ethibond Suture Granuloma following Tibialis Anterior Tendon Transfer Mimicking Osteomyelitis of Foot. J Foot Ankle Surg (Asia-Pacific) 2015;2(2):97-100.

Source of support: Nil

Conflict of interest: None

\section{INTRODUCTION}

Tibialis anterior tendon transfer is a routine procedure to correct muscle imbalance in club foot when nonoperative modalities have failed. ${ }^{1}$ There are many techniques described to anchor the transferred tendon to the bone. In our institute, ethibond number 2 suture is passed through the tendon and is tied over a button on the sole after tunneling through the lateral cuneiform. Usually, the procedure has minimal surgical complications, but some issues could potentially arise due to implanted materials. Foreign-body reaction to implanted suture after foot and ankle surgery is uncommon. There have been reports of granuloma formation after Achilles

\footnotetext{
${ }^{1}$ Assistant Professor, ${ }^{2}$ Professor and Head

${ }^{3,4}$ Senior Resident, ${ }^{5}$ Associate Professor

${ }^{1-5}$ Department of Orthopedics, Postgraduate Institute of Medical Education and Research, Chandigarh, India
}

Corresponding Author: Balaji Saibaba, Senior Resident Department of Orthopedics, Postgraduate Institute of Medical Education and Research, Chandigarh, India, Phone: 09592053573, e-mail: balajijipmer@gmail.com tendon repair in adults. ${ }^{2,3}$ In this report, we describe the clinical presentation and the successful management of a rare case of ethibond suture granuloma after tibialis anterior tendon transfer in a child with club foot, which was initially managed as infection.

\section{CASE REPORT}

A 2-year-old male child presented to our outpatient clinic in June 2011 with progressive deformation of right foot. According to history given by parents and available treatment records, the child had congenital talipes equinovarus (CTEV) at birth and was treated with Ponseti casting method which was started at the 1st month of life. The deformities got corrected at around two and a half months and the child was prescribed bracing. According to parents, the child was not tolerant to bracing and so they had casting done again at 9th month of life for another 2 months. The child now presented with an equinocavovarus foot and history revealed that the parents were not able to adhere to the bracing protocol; additionally, they were not doing any foot manipulations. The Dimeglio score at the time of presentation was 13/20. After counseling the parents about the management and bracing protocol, subsequent casting by Ponseti method was initiated and after a total of seven casts, the Dimeglio score dropped to $4 / 20$. As the child was already walking, the bracing was prescribed for a minimum of 12 to 14 hours a day, and manipulations were explained. The parents were also persuaded to encourage the child to adopt a squatting posture repeatedly.

During the follow-up period, we observed the development of a dynamic supination deformity and the parents were counseled that the child would require tibialis anterior transfer at 4 years of age. The procedure was subsequently performed in August 2013 and the whole tibialis anterior tendon distal to the extensor retinaculum was rerouted to the lateral cuneiform and was secured using nonabsorbable ethibond number 2 suture tied over a button on the sole of the foot. The patient was put on an above knee cast with ankle in dorsiflexion and foot in eversion. The cast was converted to a below knee walking cast at 3 weeks and child was mobilized. After 6 weeks, the cast and button were removed and mobilization was started, along with stretching and 
strengthening exercises. After removal of cast, the patient developed a tender hyperesthetic scar at the site of button placement. The scar hindered proper ambulation and, hence excision of scar was performed 4 weeks after cast removal. The patient started walking normally after subsequent suture removal and was without any complaints for a period of another 6 weeks. Subsequently, the patient developed a painless swelling at the dorsum and sole of the foot at the site of lateral incision, which was not associated with fever or constitutional symptoms (Figs 1 and 2). He developed a discharging sinus with serous odorless discharge. As infection was suspected, the material was sent for Gram staining and culture (including tubercular and fungal), which yielded no growth of any organisms. The discharge was persistent, and occasional greenish-colored thread pieces were noted by the parents to have been extruded. Radiology was unremarkable, fine needle aspiration cytology (FNAC) revealed only necrotic material.

Based on the clinical appearance and chronic presentation, a diagnosis of ethibond suture hypersensitivity

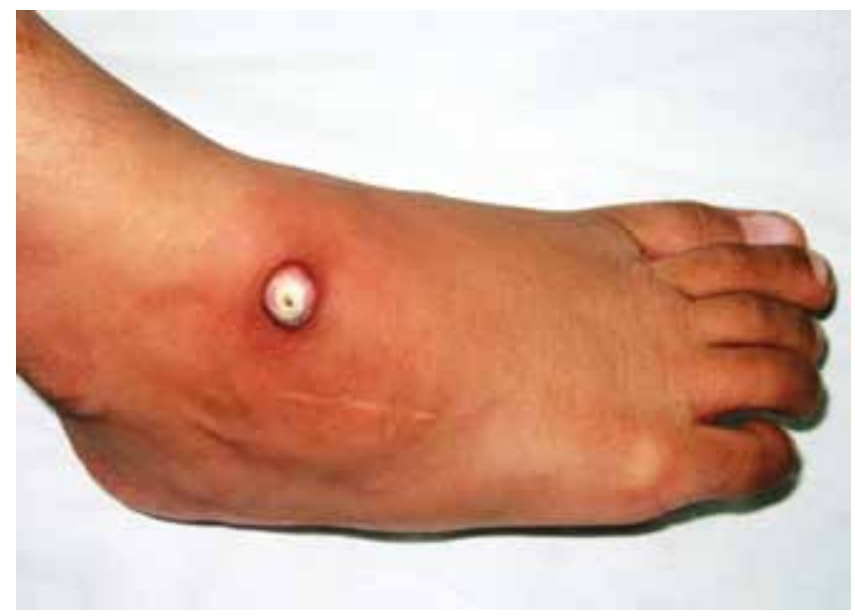

Fig. 1: Clinical photograph showing an inflamed sinus over the dorsum of the foot at the site of tendon transfer

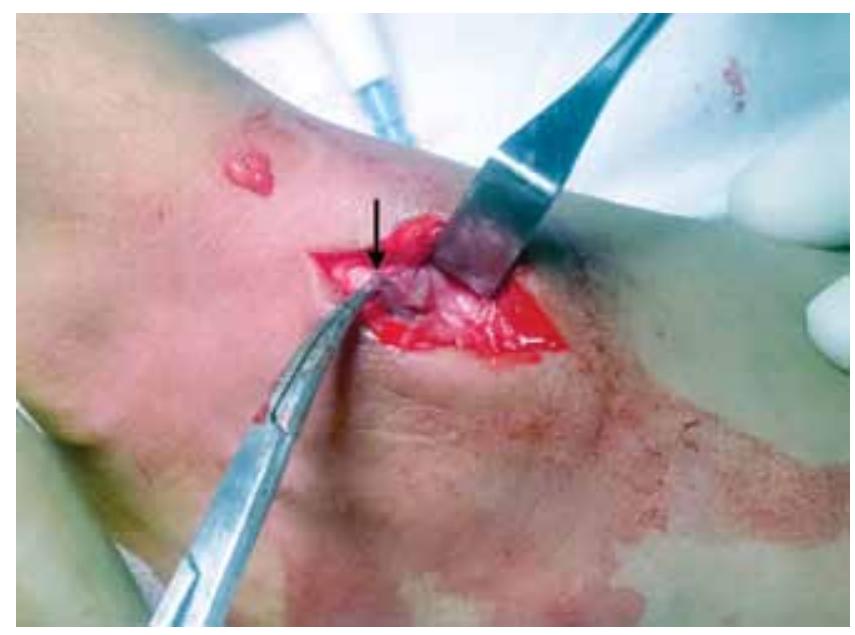

Fig. 3: Intraoperative photograph showing ethibond suture (black arrow) surrounded by granulation tissue was proposed; it was also decided to surgically explore the lesion. The incision was based on the sinus tract and on dissection, the ethibond suture material was noted to be surrounded by unhealthy tissue (Fig. 3). The suture material was removed (Fig. 4) and the tendon was found incorporated in the soft tissue and tunnel. A thorough debridement was carried out, and the plantar aspect was also incised and thoroughly washed. The wound was closed in layers and the child was kept in a below knee splint for 2 weeks. The wound healed without any complication. The patient has been pain free and walking unaided without any residual deformity at the last followup of 15 months.

\section{DISCUSSION}

Tibialis anterior tendon transfer is commonly employed for correcting dynamic supination deformity of feet following Ponseti cast correction of club foot. There are many techniques described for this procedure. Essentially, the insertion of the tendon is transferred from the inferomedial aspect of base of first metatarsal and medial

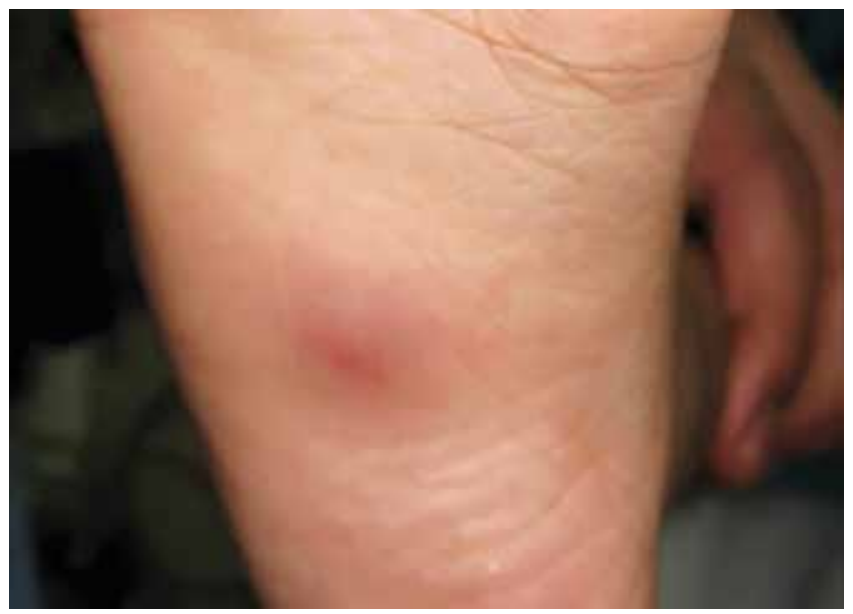

Fig. 2: Clinical photograph showing erythema on the sole at the corresponding site of tendon transfer

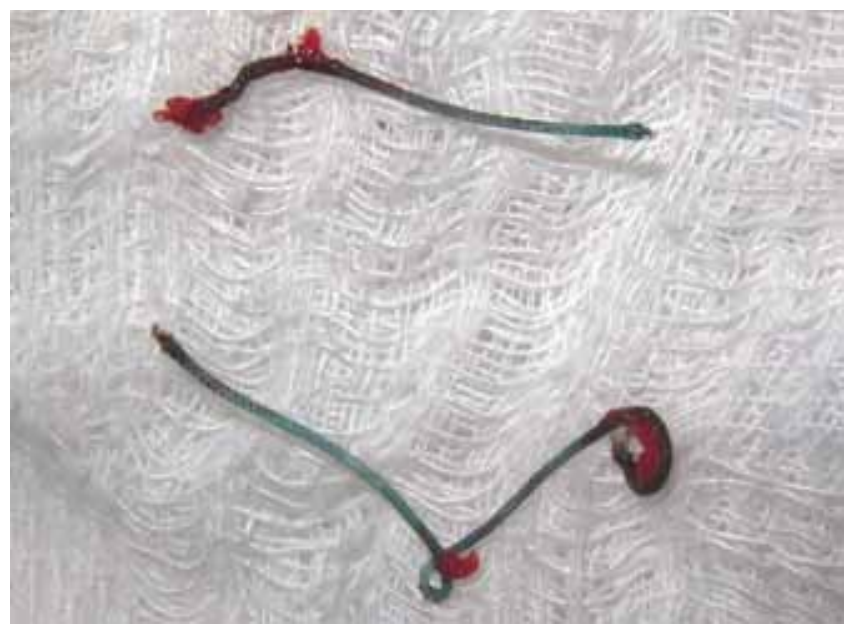

Fig. 4: Intraoperative photograph of the ethibond sutures after retrieval 
cuneiform to the dorsum of cuneiform (lateral or intermediate), base of metatarsal (3rd or 4th) or cuboid, to correct the muscle imbalance. ${ }^{1}$ The transferred tendon is held in place by means of sutures secured through the tendon which is tunneled through the bone and is anchored by one of the following ways-by suturing the tendon onto itself, by tying over a button on the plantar aspect of the foot, or by employing suture anchors or bioabsorbable interference screws. The suture commonly used is 1-0 absorbable vicryl. At our institute, we prefer ethibond no. 2 over vicryl in view of its unique physical properties.

Ethibond (Ethicon INC, Somerville, New Jersey) is a nonabsorbable, braided, synthetic suture. Basically, it comprises of polybutyrate coated polyester fibers which are braided into a multifilament strand. The polybutyrate coating decreases the 'cut-through' tendency of the polyester suture through the tissues. It has a high tensile strength and relatively low tissue reactivity. ${ }^{4}$ It is commonly utilized by surgeons in the repair of capsule, tendon and muscle.

An ideal suture material should have adequate strength not only to provide initial tissue fixation but also to maintain fixation during the healing period. ${ }^{5}$ It should be biocompatible viz-a-viz eliciting minimal tissue reaction which otherwise might hamper tissue healing or suture holding capacity. All surgical sutures elicit some degree of inflammatory response; ${ }^{6}$ suture granulomas are a result of chronic inflammatory reaction precipitated by the implanted suture material. Usually, this response is minor and not clinically apparent. Sometimes, however, an amplified tissue response can occur which can manifest as a discharging sinus or symptomatic mass. This exaggerated response will come to a halt only when the perpetrating suture is removed surgically or extruded biologically.

Esenyel et $\mathrm{al}^{6}$ studied the biologic response of three nonabsorbable suture materials in rabbit models and observed that the inflammatory reaction to ethibond in the tendon and the muscle were maximal at 3 weeks and minimal at 6 weeks postimplantation. The inflammatory reaction against ethibond decreased with time. Nevertheless, the clinical manifestations of suture granulomas may present as early as 1 week after the surgery and up to 20 years later. These might present as a slowly growing soft-tissue mass which may or may not be painful. It can mimic soft-tissue sarcoma-both clinically and radiologically, adding to the diagnostic dilemma. ${ }^{7}$ They might even manifest as discharging ulcers in and around the surgical site, which are a result of sinus tracts formed from the foreign-body granulomas to the skin.

There is paucity of literature regarding the exact incidence of suture granulomas after foot and ankle surgery (Table 1). Ethibond sutures used for Achilles tendon repair have been reported to cause symptomatic granuloma formation necessitating further surgical intervention. ${ }^{2,3}$ However, there are no published reports of foreign-body granulomas after tibialis anterior tendon transfer in pediatric age group.

Table 1: Untoward reactions reported with ethibond sutures in orthopedic surgeries

\begin{tabular}{|c|c|c|c|c|c|c|c|c|c|c|}
\hline $\begin{array}{l}\text { Sl. } \\
\text { no. }\end{array}$ & $\begin{array}{l}\text { Patient } \\
\text { (age, sex) }\end{array}$ & Surgery & Suture used & Time* & $\begin{array}{l}\text { Clinical } \\
\text { manifestation }\end{array}$ & Pathology & Treatment & Outcome & $\begin{array}{l}\text { Follow- } \\
\text { up }\end{array}$ & Author, year \\
\hline 1 & $31 \mathrm{Y}, \mathrm{M}$ & $\begin{array}{l}\text { Achilles } \\
\text { tendon repair }\end{array}$ & $\begin{array}{l}\text { Ethibond } \\
\text { no. } 2\end{array}$ & $4 \mathrm{M}$ & $\begin{array}{l}\text { Swelling, } \\
\text { discharge }\end{array}$ & $\begin{array}{l}\text { Foreign body } \\
\text { granuloma }\end{array}$ & Excision & Improved & $12 \mathrm{M}$ & $\begin{array}{l}\text { Kara A et } \mathrm{al}^{2} \\
(2014)\end{array}$ \\
\hline 2 & $58 \mathrm{Y}, \mathrm{M}$ & $\begin{array}{l}\text { Distal biceps } \\
\text { tendon repair }\end{array}$ & Ethibond & $7 Y$ & $\begin{array}{l}\text { Slowly growing } \\
\text { mass mimicking } \\
\text { soft-tissue } \\
\text { sarcoma }\end{array}$ & $\begin{array}{l}\text { Foreign body } \\
\text { granuloma }\end{array}$ & Excision & Improved & $2 M$ & $\begin{array}{l}\text { Sayari AJ } \\
\text { et } \mathrm{al}^{7}(2014)\end{array}$ \\
\hline 3 & $34 \mathrm{Y}, \mathrm{M}$ & $\begin{array}{l}\text { Achilles } \\
\text { tendon repair }\end{array}$ & Ethibond & $9 \mathrm{M}$ & $\begin{array}{l}\text { Chronic sinus } \\
\text { formation }\end{array}$ & - & $\begin{array}{l}\text { Debridement } \\
\text { and removal } \\
\text { of offending } \\
\text { suture }\end{array}$ & Improved & $3 \mathrm{M}$ & $\begin{array}{l}\text { Ahluwalia R } \\
\text { et }\left.^{3}\right|^{3}(2013)\end{array}$ \\
\hline 4 & $71 \mathrm{Y}, \mathrm{M}$ & $\begin{array}{l}\text { Open rotator } \\
\text { cuff repair }\end{array}$ & Ethibond & $15 Y$ & $\begin{array}{l}\text { Pain, reduced } \\
\text { shoulder } \\
\text { movement, } \\
\text { high CRP }\end{array}$ & $\begin{array}{l}\text { Chronic } \\
\text { osteomyelitis }\end{array}$ & $\begin{array}{l}\text { Debridement } \\
\text { and anti- } \\
\text { biotics }\end{array}$ & Improved & $3 \mathrm{M}$ & $\begin{array}{l}\text { Yeo CH } \\
\text { et } \mathrm{al}^{9}(2012)\end{array}$ \\
\hline 5 & - & $\begin{array}{l}\text { Abductor } \\
\text { reattachment } \\
\text { during THA }\end{array}$ & $\begin{array}{l}\text { Ethibond } \\
\text { no. } 5\end{array}$ & $4-7 Y$ & Osteolysis & - & - & - & $4-7 Y$ & $\begin{array}{l}\text { Kundra } \\
\text { et al }^{10} \\
(2009)\end{array}$ \\
\hline 6 & $4 \mathrm{Y}, \mathrm{M}$ & $\begin{array}{l}\text { Tibialis } \\
\text { anterior } \\
\text { tendon } \\
\text { transfer }\end{array}$ & $\begin{array}{l}\text { Ethibond } \\
\text { no. } 2\end{array}$ & $3 \mathrm{M}$ & $\begin{array}{l}\text { Swelling, } \\
\text { discharging } \\
\text { sinus }\end{array}$ & $\begin{array}{l}\text { Foreign body } \\
\text { granuloma }\end{array}$ & $\begin{array}{l}\text { Debridement } \\
\text { and removal } \\
\text { of offending } \\
\text { suture }\end{array}$ & Improved & $15 \mathrm{M}$ & $\begin{array}{l}\text { Current } \\
\text { study }\end{array}$ \\
\hline
\end{tabular}

*Time interval between surgical procedure and postoperative clinical manifestation; Y: Years; M: Male; M: Months; CRP: C-reactive protein; THA: Total hip arthroplasty 
Whenever there is a discharging ulcer in the vicinity of a surgical site, infection has to be ruled out. This suspicion should be further heightened when a synthetic nonabsorbable 'braided' suture like ethibond has been utilized in the preceding surgery. It is a well known fact that multifilament sutures have a higher propensity for infection than monofilament sutures. ${ }^{8,9}$ Hence, Gram stain, bacteriological culture and meticulous histopathological examination are of paramount importance in ruling out infection. In our case, neither any organism was detected by any of the above methods nor did the patient have symptoms of fever or pain clinically.

Apart from soft-tissue manifestations, there have been reports of ethibond sutures having deleterious effects on bone and cartilage. Kundra et $\mathrm{a}^{10}$ reported the occurrence of osteolytic pattern of bone reaction around the bone tunnels in those cases in which ethibond was used for abductor reattachment during total hip arthroplasty. Based on the study of nonabsorbable sutures (including ethibond) in murine models, Lovric et $\mathrm{al}^{11}$ hypothesized that the inflammatory response elicited in response to suture wear debris might lead to chondrolysis. Even though there has not been any orthopedic literature citing similar occurrences in the pediatric population and since ethibond sutures are virtually 'nonabsorbable', orthopedicians must be aware of the plausible deleterious biologic reactions that might be associated with the use of ethibond sutures in the immature skeleton.

\section{CONCLUSION}

Foreign-body granuloma formation can occur with the use of ethibond sutures for tendon transfer in pediatric age group. They can clinically present as a symptomatic mass or a discharging sinus. Surgical excision is the treatment of choice.

\section{REFERENCES}

1. Lampassi M, Bettuzzi C, Palmonari M, Donzel O. Transfer of the tendon of tibialis anterior in relapsed congenital clubfoot-long-term results in 38 feet. J Bone Joint Surg Br $2010 \mathrm{Feb} ; 92 \mathrm{~B}(2): 277-283$.

2. Kara A, Celik H, Seker A, Uysal MA, Uzun M, Malkoc M. Granuloma formation secondary to Achilles tendon repair with non-absorbable suture. Int J Surg Case Rep 2014; 5(10):720-722.

3. Ahluwalia R, Zourelidis C, Guo S, Dega R. Chronic sinus formation using nonabsorbable braided suture following open repair of Achilles tendon. Foot Ankle Surg 2013;19 (2):e7-e9.

4. Capperauld I. Suture materials: a review. Clin Mater 1989; 4(1):3-12.

5. Barber FA, Herbert MA, Richards DP. Sutures and suture anchors: update 2003. Arthroscopy 2003 Nov;19(9):985-990.

6. Esenyel CZ, Demirhan M, Kilicoglu O, Adanir O, Bilgic B, Güzel $O$, et al. Evaluation of soft-tissue reactions to three nonabsorbable suture materials in a rabbit model. Acta Orthop Traumatol Turc 2009 Aug-Oct;43(4):366-372.

7. Sayari AJ, Pretell-Mazzini J, Jose J, Conway SA. Distal biceps brachii tendon repair complicated by a suture granuloma mimicking a soft-tissue sarcoma: a case report and review of the literature. J Shoulder Elbow Surg 2014 Aug;23(8): e191-e197.

8. Alexander JW, Kaplan JZ, Altemeier WA. Role of suture materials in the development of wound infection. Ann Surg 1967 Feb;165(2):192-199.

9. Yeo $\mathrm{CH}$, Russell NC, Sharpe T. Non-absorbable suture induced osteomyelitis: a case report and review of the literature. Case Rep Orthop 2012. Article 381490.

10. Kundra RK, Karim SN, Lawrence T. Osteolysis of the greater trochanter following reattachment of hip abductors using polyester suture in total hip arthroplasty. Hip Int 2009 JulSep;19(3):274-278.

11. Lovric V, Heuberer P, Goldberg M, Stone D, Page R, Oliver R, et al. Biologic response to orthopaedic suture wear-debris: a histological study in a murine air pouch model. Bone Joint J 2013;95B(Supp):15-244.

\footnotetext{
"Please visit www.jfasap.com for instructions to authors and copyright form.
} 